\title{
Preliminary Laboratory Study of Plutonium-238 Dissolution from Mound Soil by Means of the $\mathrm{ACT}^{\star} \mathrm{DE}^{\star} \mathrm{CON}^{\mathrm{SM}}$ Process
}

by K.A. Brown, ${ }^{*}$ R.R. Heinrich, ${ }^{*}$ D.O. Johnson, and D.E. Edgar

Energy Sysiems Clivision,

Argonne National Laboratory, 9700 South Cass Avenue, Argonne, Illinois 60439

April 1992

Work sponsored by United States Department of Energy,

Office of Environmental Restoration and Waste Management, Office of Technology Deveiopment

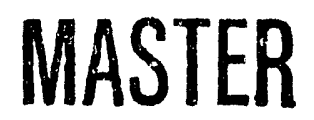

"Brown is affiliated with Information and Publishing Division and Heinrich with Chemical Technology Division. 


\section{Contents}

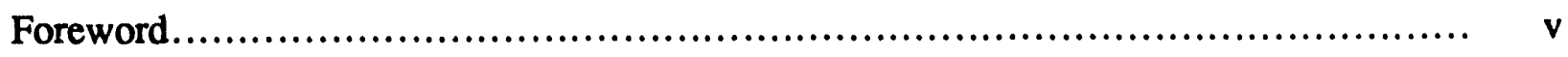

Abstract................................................................................ 1

1 Introduction......................................................................... 1

1.1 Background.................................................................. 1

1.2 Principle of ACT*DE*CONSM Testing...................................... 2

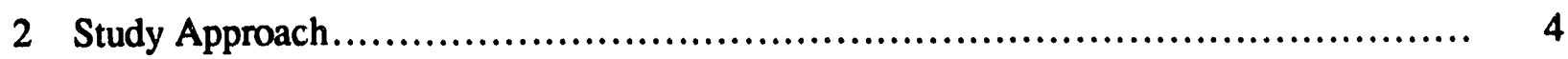

2.1 Soil Preparation and Analysis ................................................... 4

2.2 ACT $^{*}$ DE$^{*}$ CONSM Dissolution Studies ....................................... 5

3 Results and Discussion.......................................................... 6

4 Conclusions and Recommendations for Further Work ....................................... 12

4.1 Phase II: Laboratory-Scale Optimization ..................................... 12

4.2 Phase III: Pilot-Scale Testing .............................................. 14

4.3 Phase IV: Full-Scale Demonstration ...................................... 15

Appendix A: External Analysis Reports.......................................... 17

Appendix B: Recovery of Pu-238 from Mound Soil by Means of the ACT*DE*CONSM

Process: Soil Spiking and Pu-238 Dissolution ......................... 33

Figures

1 Percentage Recovery of Pu-238 from Sample A ................................ 10

2 Percentage Recovery of Pu-238 from Sample B ................................ 10

\section{Tables}

1 Material Balance for Spiking of Mound Soil .................................... 7

2 Material Balance for Mound Sample A ............................................. 8 


\section{Tables (Cont.)}

3 Material Balance for Mound Sample B ...................................... 9

4 Comparison of the Results of Pu-238 Analyses ................................... 11 


\section{Foreword}

In this report, the tests performed, results achieved, conclusions drawn, and recommendations made with respect to the effectiveness of the ACT*DE*CONSM process are presented. This material was reviewed by an EG\&G Mound Applied Technologies (Mound) staff member, who concurred with the conclusions and recommendations presented in this report regarding the potential for using the $A C T^{*} \mathrm{DE}^{*} \mathrm{CON}{ }^{\mathrm{SM}}$ process to treat Mound soils. 


\title{
Preliminary Laboratory Study of Plutonium-238 Dissolution from Mound Soil by Means of the ACT*DE*CONSm Process
}

\author{
by
}

\author{
K.A. Brown, R.R. Heinrich, D.O. Johnson, and D.E. Edgar
}

\begin{abstract}
The treatment of contaminated soil presents a significant technical problem. Soil-washing and chemical-extraction methods have proven to be effective for specific applications, but a process with more comprehensive treatment properties that is both cost-effective and environmentally propitious is needed. Bradtec, Inc., has developed a process, the $A C T^{*} D E * C O N S M$ process, that has been tested on soil contaminated with plutonium. The process effectively extracted $\mathrm{Pu}-238$ after three washes, reducing the contamination levels from approximately $20 \mathrm{~Bq} / \mathrm{g}$ to $1.6-1.9 \mathrm{~Bq} / \mathrm{g}$ and yielding a decontamination factor ranging from 11 to 13 . By using four or more $A C T * D E^{*} C O N^{S M}$ washes or a continuous-flow process with ACT*DE*CONSM solvents on a pilot-scale test, a target decontamination level of $0.93 \mathrm{~Bq} / \mathrm{g}$ might be achievable.
\end{abstract}

\section{Introduction}

\subsection{Background}

The removal and/or treatment of contaminated soils is a major problem facing the U.S. Department of Energy (DOE) and the U.S. Environmental Protection Agency (EPA) Superfund program. The Department of Energy has identified several sites that have contaminated soil as a result of past disposal and waste burial practices. In terms of the vulume of contaminated material, two sites illustrate the magnitude of this problem: the EG\&G Mound Applied Technologies site (referred to as the Mound site) in Miamisburg, Ohio, at which the estimated total volume of soil to be recovered or treated is approximately $4 \times 10^{6} \mathrm{ft}^{3}$, and the Idaho National Engineering Laboratory (INEL), at which the total volume of contaminated soil in the Radioactive Waste Management Complex is approximately $10 \times 10^{6} \mathrm{ft}^{3}$. Other sites with significant soilcontamination problems include Hanford and Savannah River.

Approaches to the treatment of soils contaminated with radionuclides and heavy metals have inciuded the removal of the soil and its subsequent disposal in a controlled burial site, soil washing, and chemical extraction. Each of these methods has environmental, procedural, and 
regulatory shortcomings. Therefore, a more effective treatment process is needed. Such a process would have the following characteristics:

- Be selective (i.e., recover only contaminants, leaving nonhazardous minerals with the treated soil),

- Produce low volumes of waste (ideally, close to the volume of contaminant recovered) and no secondary wastes,

- Use environmentally benign solvents, and

- Allow for the recovery of the contaminants for recycling or disposal with relative ease.

Ideally, the goal of treating contaminated soil is to decrease the levels of contaminants to meet EPA standards while the treated, natural soil is allowed to remain in place.

Bradtec, Inc., has developed and tested a dilute, aqueous-based chemical-extraction process that, according to Bradtec representatives, has the desired characteristics. This process is called the ACT ${ }^{*} D E * C O N S M$ process. The $A C T * D E * C O N^{S M}$ process can be applied either ex situ or in situ. Bradtec reports that in tests of the process, the levels of contamination in soil have been decreased to less than $1.3 \mathrm{~Bq} / \mathrm{g}$ for uranium and less than $0.93 \mathrm{~Bq} / \mathrm{g}$ for plutonium. The process can also be used to treat materials other than soil, including large process vessels (e.g., enrichment plant components), hot cells, or military vehicles contaminated with depleted uranium.

The Department of Energy, through Argonne National Laboratory (ANL), issued a contract to Bradtec for testing the $A C T * D E * C O N^{S M}$ process in the treatment of plutonium-contaminated soils at the Mound site. This contract was for the first phase of the research, described herein as the Phase I laboratory study. The testing performed during and the results obtained from the Phase I work are provided in this report. The tasks to be undertaken in subsequent phases are described in Section 4.

\subsection{Principle of $A C T^{\star} D E^{\star} C O N S M$ Testing}

Clean soil from a chosen site is contaminated with the radionuclide(s) of interest by using a technique known as spiking. Spiking involves bringing the soil into contact with a known amount of the contaminant - in this instance, $\mathrm{Pu}-238$. The soil and a solution containing the contaminant are stirred together for several hours, and then the solution is filtered. The contact solution is analyzed for any residual contamination. The soil is the. washed at least three times with water to remove interstitial contamination (i.e., contamination that is not truly sorbed onto the soil but lies between the particles in the soil). The amount of contaminant sorbed onto the soil is determined by 
subtracting the concentration of contaminant found in the contact solution and washings from the original concentration of contaminant used in the spike. The amount of contaminant sorbed onto the soil also can be determined by leaching, a procedure that uses strongly acidic solutions under forcing conditions to recover the contaminant from the soil.

The spiked soil was used in tests of the $A C T * D E * C O N^{S M}$ process. The soil was washed with $A C T^{*} \mathrm{DE}^{*} \mathrm{CON}^{\mathrm{SM}}$ wash solutions, and the extent of decontamination was determined by measuring the concentration of contaminant in each of the ACT*DE*CONSM wash solutions. After the $A C T^{*} \mathrm{DE}^{*} \mathrm{CONSM}$ treatment, the soil was leached to determine the concentration of contaminant that remained on the soil. The ratio of the contaminant concentration on the spiked soil to the contaminant concentration on the treated soil is the decontamination factor (DF). ${ }^{\dagger}$

The test described in this report details the dissolution and extraction of $\mathrm{Pu}-238$ from Mound soil that had been contaminated by spiking it with Pu- 238 .

† The DF gives the level of decontamination of the soil obtained after three ACT*DE*CONSM washes. The DF is calculated by dividing the Pu-238 activity on the spiked soil by the Pu-238 activity left on the soil after the $A C T^{*} D E^{*} C^{S O N}{ }^{S M}$ washes. 


\section{Study Approach}

The objective of this study is to validate the potential of the Bradtec proprietary ACT $*$ DE*CON ${ }^{S M}$ process for extracting plutonium contaminants from soil. This study represents Phase I of the ACT*DE*CON ${ }^{* M}$ tests on Mound soil. The tests were carried out in Bradtec's laboratory and were witnessed by Robert R. Heinrich of ANL. The tests were conducted on uncontaminated soil, which was spiked by Bradtec with Pu-238. The study encompassed soil preparation and analysis, as well as the $\mathrm{ACT} * \mathrm{DE}^{*} \mathrm{CON}^{\mathrm{SM}}$ dissolution studies. These tasks are described in the following sections.

\subsection{Soil Preparation and Analysis}

The raw soil sample (sediment) received from the Mound site was dry-sieved to collect and homogenize the silt and clay fractions of the soil and to produce a batch of soil typical of the sediment in the Miami Erie Canal. This standard batch of soil was thoroughly characterized. The uncontaminated, sieved, and blended Mound soil was analyzed by Bradtec and outside laboratories for the following parameters (see Appendix A for the results of the characterization):

- Particle size;

- Mineralogy;

- Organic carbon content;

- Iron, calcium, magnesium, and manganese content;

- Ion exchange capacity;

- Carbonates;

- $\mathrm{pH} ;$ and

- Soil Eh.

Because the Mound soil has a high calcite content, there was concern that the spiking procedure would dissolve the calcite, thereby changing the characteristics of the soil to be tested. To minimize these effects, the soil sample used for dissolution testing consisted of approximately four parts sieved, unspiked soil and one part sieved, spiked soil blended together. Mixing ensured 
that the natural calcite content of the spiked soil would be replenished by the calcite in the unspiked soil should the spiking procedure dissolve the calcite.

After the characterization, portions of the soil were spiked with Pu-238 for use in the $A C{ }^{*} D^{*}{ }^{*} C O N^{S M}$ dissolution tests (see Appendix B, Section B.1, for the soil spiking procedure). The contaminant was applied as a spike of $\mathrm{Pu}-238$ in the form of plutonium nitrate under mildly acidic conditions. To compensate for any losses in soil volume attributable to the dissolution of the calcite, the spiked sample was combined with four times its weight of unspiked soil. The soil was spiked initially with $99.9 \pm 1.8 \mathrm{~Bq} / \mathrm{g}(2697 \pm 48.6 \mathrm{pCi} / \mathrm{g})$ of $\mathrm{Pu}-238$ so that a sample of $19.8 \pm 0.4 \mathrm{~Bq} / \mathrm{g}(533.3 \pm 9.7 \mathrm{pCi} / \mathrm{g}) \mathrm{Pu}-238$ could be obtained after tise soil was mixed with a larger volume of unspiked soil. The clean soil was stirred with the spiked soil for a limited period (the contact time of the spiked soil with the clean soil was shortened so that the test could be completed while the ANL representative was present).

\subsection{ACT*DE*CONSM Dissolution Studies}

The dissolution studies were conducted in two parts. First, the ACT*DE*CONSM formulation was optimized, and second, the Mound soil was tested by using the optimized formulation. Because the Mound soil sample arrived late at Bradtec's laboratory, the optimization runs were performed on a non-Mound soil sample blended by Bradtec. This soil was high in clay and silt and was made up of a blend of various soils. After the optimization runs, the $A C T * D E * C O N S M$ process was tested by using two samples of spiked soil from the Mound site. An outline of the test procedure is provided in Appendix B, Section B.2.

After the soil was spiked and washed, it was divided into three 5-g portions. The dissolution tests were performed on two of these portions, labeled A and B, by using three $A C T * D E * C O N S M$ washes. The third portion, labeled $C$, was used to determine the concentration of $\mathrm{Pu}-238$ sorbed onto the soil. Some of the soil from sample $\mathrm{C}$ was sent to Harwell Laboratories in the United Kingdom and to ANL for independent analyses.

After completion of the dissolution studies at Bradtec, Robert Heinrich applied custody seals to all sample vials. Soil samples were then sent to ANL, Harwell Laboratories, and British Rail (BritRail) Laboratories (in the United Kingdom) for analysis of Pu-238. Bradtec also analyzed the soil samples and he wash solutions and completed a mass balance on the soil and dissolution liquors. 


\section{Results and Discussion}

The data gathered as a result of $A C T * \mathrm{DE}^{*} \mathrm{CON}{ }^{\mathrm{SM}}$ dissolution studies quantitatively demonstrated that the ACT*DE*CONSM process could be used to extract Pu-238 from Mound soil. In this section, the data are presented and discussed.

Table 1 shows the activity balance for the spiking of clean soil from the Mound facility with Pu-238. Because $1.5 \mathrm{~mL}$ of Pu-238 standard (Pu-238 activity equal to $199.8 \pm 3.6 \mathrm{~Bq} / \mathrm{g}[5394.6 \pm 97.2 \mathrm{pCi} / \mathrm{g}])$ was used to spike $3 \mathrm{~g}$ of clean soil, the amount of $\mathrm{Pu}-238$ used was $299.75 \pm 5.4 \mathrm{~Bq}(8093.3 \pm 146 \mathrm{pCi})$. A total of $3.35 \mathrm{~Bq}(90.47 \mathrm{pCi})$ of $\mathrm{Pu}-238$ was found in the contact liquor and washings, which was subtracted from the original spike to give the theoretical amount of $\mathrm{Pu}-238$ on the spiked soil: $296.4 \pm 5.4 \mathrm{~Bq}$ $(8002.8 \pm 146 \mathrm{pCi})$. The $3 \mathrm{~g}$ of spiked soil was then blended with $12 \mathrm{~g}$ of clean soil. Thus, the theoretical amount of Pu-238 on the blended soil was $19.75 \pm 0.4 \mathrm{~Bq} / \mathrm{g}$ $(533.3 \pm 9.7 \mathrm{pCi} / \mathrm{g})$. This value was confirmed by analyzing two leachates from the spiked soil. The results from these analyses were $20.51 \pm 0.63 \mathrm{~Bq} / \mathrm{g}(553.9 \pm 16.4 \mathrm{pCi} / \mathrm{g}) \mathrm{Pu}-238$ and $20.34 \pm 0.38 \mathrm{~Bq} / \mathrm{g}(549.1 \pm 10.1 \mathrm{pCi} / \mathrm{g}) \mathrm{Pu}-238$ in the soil, respectively.

Tables 2 and 3 show the activity balance for the ACT*DE*CONSM test on sample $A$ and the duplicate, sample B, respectively. The total Pu-238 activity used in the test was obtained by multiplying the Pu-238 activity per gram of soil by the weight of the soil used in each test. The activity removed is recorded for each $A C T * D E * C O N^{S M}$ wash and is expressed as a percentage of the original activity. The percentage removal of Pu-238 after three ACT*DE*CONSM washes was found to be $83.8 \%$ for sample $A$ and $89.5 \%$ for sample 3 . Tables 2 and 3 also show that by using ACT*DE*CONSM washes, a DF of 11 was achieved for sample $A$, and a DF of 13 was achieved for sample B. The percentage recoveries for each test are shown in Figures 1 and 2 for samples A and B, respectively.

The soil remaining after treatment with the ACT*DE*CONSM process was analyzed by using the same leaching procedure as that for the spiked soil. The amount of Pu-238 found in treated soil sample A was $1.85 \pm 0.2 \mathrm{~Bq} / \mathrm{g}(50 \pm 5.4 \mathrm{pCi} / \mathrm{g})$, and the amount of $\mathrm{Pu}-238$ found in treated sample B was $1.59 \pm 0.1 \mathrm{~Bq} / \mathrm{g}(42.8 \pm 3.2 \mathrm{pCi} / \mathrm{g})$. The total quantity of Pu-238 recovered in the $A C T * D E * C O N S M$ process for each sample was obtained by adding the total amount of Pu-238 in the wash solution after the ACT*DE*CONSM treatment to the amount of $\mathrm{Pu}-238$ remaining on the treated soil. Each total was expressed as a percentage of the original activity $-92.8 \%$ for sample A and $97.2 \%$ for sample B.

To confirm the accuracy of the analyses, Harwell Laboratories and ANL analyzed replicate samples used in the ACT ${ }^{*} D E * C O N S M$ process. Table 4 lists the results obtained from each research laboratory. The results were found to be in excellent agreement. 
TABLE 1 Material Balance for Spiking of Mound Soil

\begin{tabular}{lcc}
\hline \multicolumn{1}{c}{ Sample } & $\begin{array}{c}\text { Total Activity of } \\
\text { Pu-238 } \\
(\mathrm{Bq})\end{array}$ & $\begin{array}{c}\text { Proportion of } \\
\text { Pu-238 } \\
(\mathrm{Bq} / \mathrm{g})\end{array}$ \\
\hline & $299.8 \pm 5.4$ & $99.9 \pm 1.8$ \\
Original spike on $3 \mathrm{~g}$ of soil & $(8093.3 \pm 146)^{\mathrm{a}}$ & $(2697.3 \pm 48.6)^{\mathrm{b}}$ \\
& $1.5 \pm 0.6$ & $0.49 \pm 0.25$ \\
Contact liquor & $(40.2 \pm 17)^{\mathrm{a}}$ & $(13.3 \pm 5.7)^{\mathrm{b}}$ \\
& $0.48 \pm 0.04$ & $0.16 \pm 0.01$ \\
First water wash of soil & $(13 \pm 1.0)^{\mathrm{a}}$ & $(4.3 \pm 0.4)^{\mathrm{b}}$ \\
& $0.44 \pm 0.025$ & $0.15 \pm 0.01$ \\
Second water wash of soil & $(12 \pm 0.75)^{\mathrm{a}}$ & $(4.0 \pm 0.25)^{\mathrm{b}}$ \\
& & \\
Third water wash of soil & $0.34 \pm 0.025$ & $0.11 \pm 0.01$ \\
& $(9.2 \pm 0.75)^{\mathrm{a}}$ & $(3.0 \pm 0.25)^{\mathrm{b}}$ \\
Water wash from blending spiked soil with & $0.60 \pm 0.025$ & $0.20 \pm 0.01$ \\
unspiked soil & $(16.4 \pm 0.8)^{\mathrm{a}}$ & $(5.4 \pm 0.25)^{\mathrm{b}}$ \\
Total activity in water washes & 3.35 & 1.12 \\
\hline
\end{tabular}

a Values in parentheses are in pCi.

b Values in parentheses are in $\mathrm{pCi} / \mathrm{g}$. 
TABLE 2 Material Balance for Mound Sample A

\begin{tabular}{|c|c|c|c|}
\hline Samplea & $\begin{array}{c}\text { Total Activity of } \\
\text { Pu-238 } \\
\text { (Bq) }\end{array}$ & $\begin{array}{l}\text { Proportion of } \\
\text { Pu-238 } \\
(\mathrm{Bq} / \mathrm{g})\end{array}$ & $\begin{array}{c}\text { Activity in } \\
\text { Different } \\
\text { Streams } \\
(\%)\end{array}$ \\
\hline Spiked soil & $\begin{aligned} 102.9 & \pm 3.5 \\
(2779.4 & \pm 84.4)^{b}\end{aligned}$ & $\begin{aligned} 20.51 & \pm 0.63 \\
(553.9 & \pm 16.4)^{c}\end{aligned}$ & - \\
\hline First ACT"DE"CONSM wash & $\begin{array}{c}75.7 \pm 8.2 \\
(2044.6 \pm 220.5)^{b}\end{array}$ & $\begin{array}{c}15.1 \pm 1.6 \\
(408.2 \pm 44.1)^{c}\end{array}$ & 73.7 \\
\hline Second ACT"DE"CONSM wash & $\begin{aligned} 4.7 & \pm 1.0 \\
(125.9 & \pm 26.5)^{b}\end{aligned}$ & $\begin{array}{r}0.93 \pm 0.25 \\
(25.2 \pm 0.5)^{c}\end{array}$ & 4.5 \\
\hline Third ACT"DE*CONSM wash & $\begin{aligned} 5.8 & \pm 1.3 \\
(156.5 & \pm 31.5)^{b}\end{aligned}$ & $\begin{array}{r}1.15 \pm 0.25 \\
(31.0 \pm 6.3)^{c}\end{array}$ & 5.6 \\
\hline $\begin{array}{l}\text { Total PU-238 after ACT*DE*CONSM } \\
\text { washes }\end{array}$ & $\begin{array}{c}86.2 \\
(2327.0)^{b}\end{array}$ & $\begin{array}{c}17.2 \\
(464.4)^{c}\end{array}$ & 83.8 \\
\hline Treated, spiked soil & $\begin{aligned} 9.3 & \pm 1.3 \\
(251.1 & \pm 35)^{b}\end{aligned}$ & $\begin{array}{l}1.85 \pm 0.2 \\
(50.0 \pm 5.4)^{c}\end{array}$ & 9.0 \\
\hline Total Pu-238 recovelod & $\begin{array}{c}95.5 \\
(2578)^{b}\end{array}$ & $\begin{array}{c}19.0 \\
(514.3)^{c}\end{array}$ & 92.8 \\
\hline
\end{tabular}

a Weight of soil used in the ACT*DE*CONSM test $=5.0177 \mathrm{~g}$; DF $(102.9 \mathrm{~Bq} / 9.3 \mathrm{~Bq})=11.1$.

b Values in parentheses are in $\mathrm{pCi}$.

- Values in parentheses are in $\mathrm{pCi} / \mathrm{g}$. 
TABLE 3 Material Balance for Mound Sample B

\begin{tabular}{|c|c|c|c|}
\hline Samplea & $\begin{array}{c}\text { Total Activity of } \\
\text { Pu-238 } \\
\text { (Bq) }\end{array}$ & $\begin{array}{l}\text { Proportion of } \\
\text { Pu-238 } \\
(\mathrm{Bq} / \mathrm{g})\end{array}$ & $\begin{array}{c}\text { Activity in } \\
\text { Different } \\
\text { Streams } \\
(\%)\end{array}$ \\
\hline Spiked soil & $\begin{aligned} 102.9 & \pm 3.2 \\
(2779.4 & \pm 84.4)^{b}\end{aligned}$ & $\begin{array}{c}20.51 \pm 0.63 \\
(553.9 \pm 16.4)^{c}\end{array}$ & - \\
\hline First ACT'DE*CONSM wash & $\begin{aligned} 72.8 & \pm 5.5 \\
(1966.4 & \pm 149.9)^{b}\end{aligned}$ & $\begin{array}{c}14.6 \pm 1.1 \\
(393.0 \pm 30.2)^{c}\end{array}$ & 70.8 \\
\hline Second ACT*DE"CONSM wash & $\begin{array}{c}14.5 \pm 0.8 \\
(391.2 \pm 18.9)^{b}\end{array}$ & $\begin{array}{c}2.9 \pm 0.1 \\
(78.2 \pm 3.8)^{c}\end{array}$ & 14.1 \\
\hline Third ACT*DE*CONSM wash & $\begin{aligned} 4.8 & \pm 0.9 \\
(129.3 & \pm 22.7)^{b}\end{aligned}$ & $\begin{array}{r}1.0 \pm 0.1 \\
(25.8 \pm 5)^{c}\end{array}$ & 4.6 \\
\hline $\begin{array}{l}\text { Total Pu-238 after ACT"DE"CONSM } \\
\text { washes }\end{array}$ & $\begin{array}{c}92.1 \\
(2486.9)^{b}\end{array}$ & $\begin{array}{c}18.4 \\
(496.9)^{c}\end{array}$ & 89.5 \\
\hline Treated, spiked soil & $\begin{aligned} 7.9 & \pm 0.6 \\
(213.3 & \pm 16.2)^{b}\end{aligned}$ & $\begin{array}{l}1.59 \pm 0.1 \\
(42.8 \pm 3.8)^{c}\end{array}$ & 7.7 \\
\hline Total Pu-238 recovered & $\begin{array}{c}100.0 \\
(2701.2)^{b}\end{array}$ & $\begin{array}{c}20.0 \\
(539.8)^{c}\end{array}$ & 97.2 \\
\hline
\end{tabular}

- Weight of soil used in the ACT'DE*CONSM test $=5.004 \mathrm{~g} ;$ DF $(102.9 \mathrm{~Bq} / 7.9 \mathrm{~Bq})=13$.

b Values in parentheses are in $\mathrm{PCi}$.

c Values in parentheses are in pCi/g. 


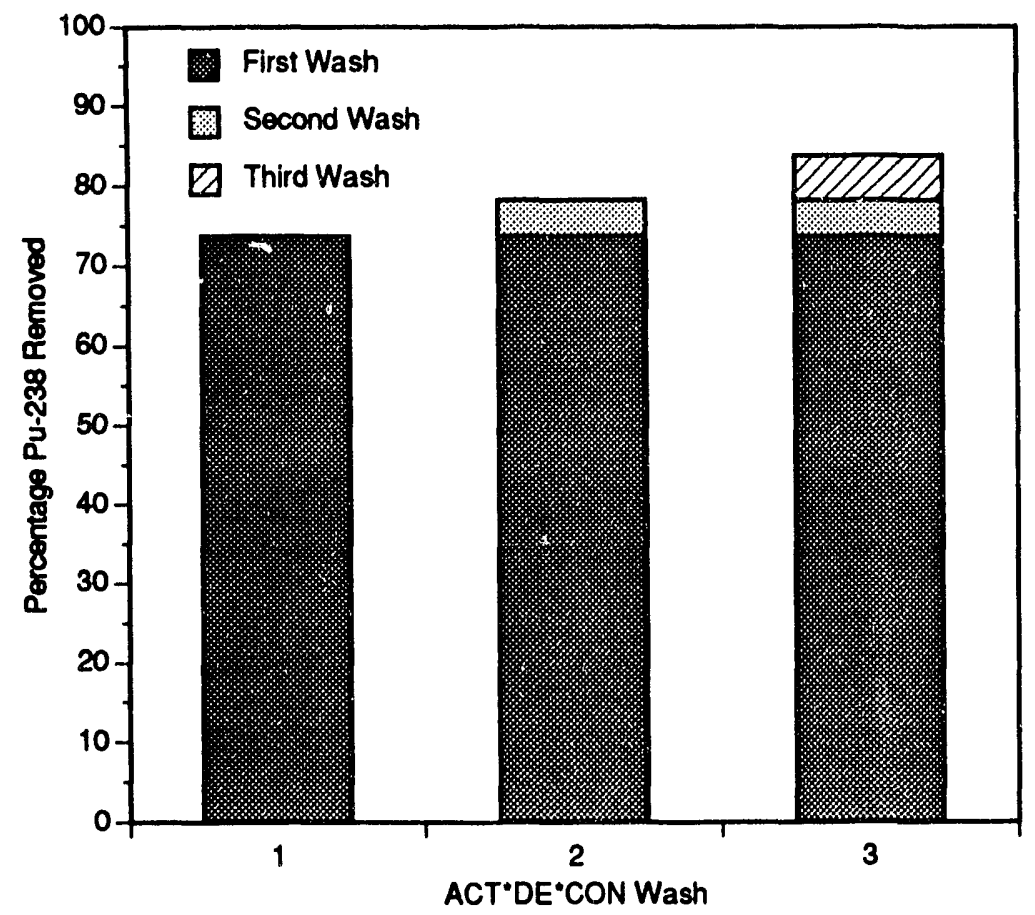

FIGURE 1 Percentage Recovery of Pu-238 from Sample A

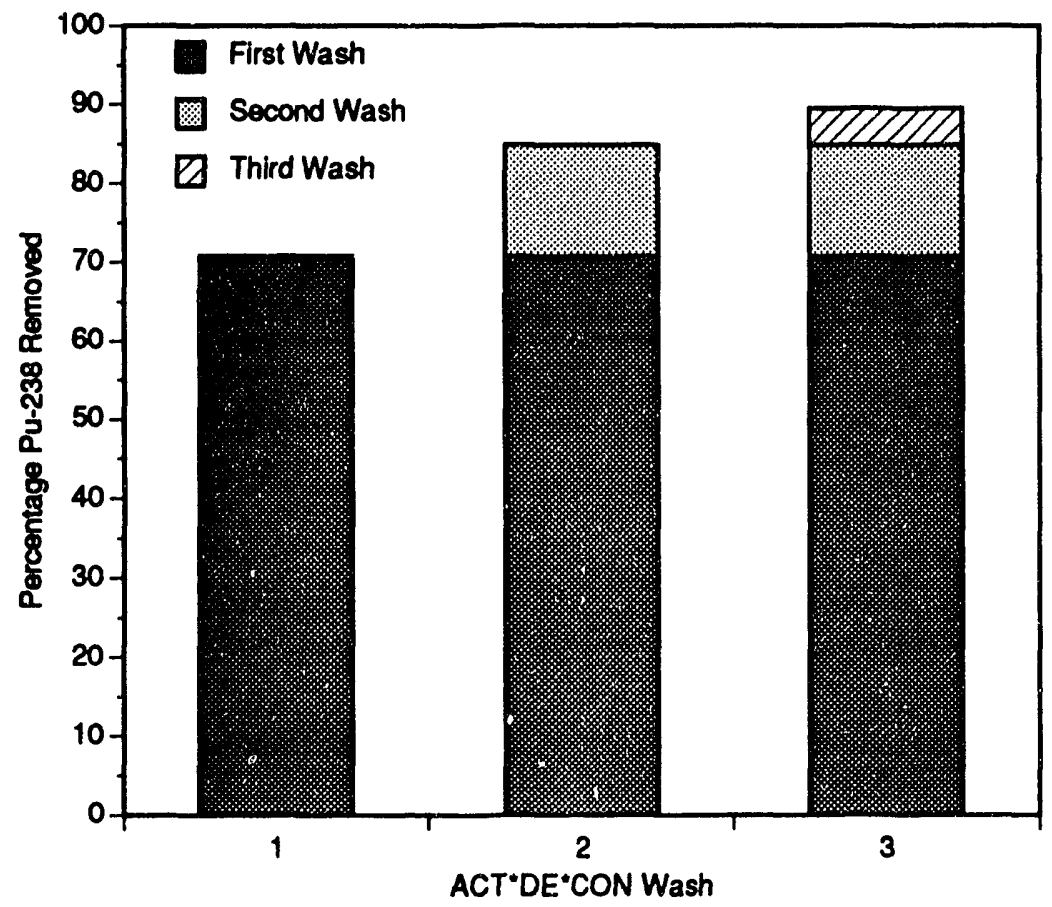

FIGURE 2 Percentage Recovery of Pu-238 from Sample B 
TABLE 4 Comparison of the Results of Pu-238 Analyses

\begin{tabular}{|c|c|c|c|}
\hline \multirow[b]{2}{*}{ Sample } & \multicolumn{3}{|c|}{ Results of Pu-238 Analyses, by Laboratory $(\mathrm{Bg} / \mathrm{g})$} \\
\hline & Argonno & Bradtec & Harwell \\
\hline Spiked Mound soil & $\begin{array}{l}22.38 \pm 1.28 \\
(604.35 \pm 34.62)^{2}\end{array}$ & $\begin{array}{l}20.51 \pm 0.63 \\
(553.9 \pm 16.4)\end{array}$ & $\begin{array}{l}20.3 \pm 0.7 \\
(548 \pm 19)\end{array}$ \\
\hline $\begin{array}{l}\text { Spiked Mound soil, } \\
\text { duplicate }\end{array}$ & $\begin{array}{l}19.77 \pm 1.79 \\
(533.86 \pm 48.26)\end{array}$ & $\begin{array}{l}20.34 \pm 0.38 \\
(549.1 \pm 10.1)\end{array}$ & - \\
\hline $\begin{array}{l}\text { Treated Mound soil, } \\
\text { Sample A }\end{array}$ & $\begin{array}{l}2.16 \pm 0.12 \\
(58.43 \pm 3.30)\end{array}$ & $\begin{array}{l}1.85 \pm 0.2 \\
(50 \pm 5.4)\end{array}$ & $\begin{array}{l}1.88 \pm 0.08 \\
(50.8 \pm 2.2)\end{array}$ \\
\hline $\begin{array}{l}\text { Treated Mound soil, } \\
\text { Sample B }\end{array}$ & $\begin{array}{l}1.57 \pm 0.1 \\
(42.51 \pm 2.58)\end{array}$ & $\begin{array}{l}1.59 \pm 0.1 \\
(42.9 \pm 3.2)\end{array}$ & - \\
\hline
\end{tabular}

a Values in parentheses are in $\mathrm{pCi} / \mathrm{g}$.

The target level of decontamination was $0.93 \mathrm{~Bq} / \mathrm{g}$. Three separate ACT*DE*CONSM washes of the soil reduced the level of contamination from approximately $20 \mathrm{~Bq} / \mathrm{g}$ to $1.85 \pm 0.2 \mathrm{~Bq} / \mathrm{g}$ for sample $\mathrm{A}$ and $1.58 \pm 0.1 \mathrm{~Bq} / \mathrm{g}$ for sample $\mathrm{B}$. Recent tests in which the $A C T^{*} D^{*} C O N^{S M}$ process was used to remove uranium and thorium from soil have shown that considerably larger DFs are achievable with four or more washes. Thus, by using a system (such as a continuous-flow system) in which the soil is successively washed with fresh ACT*DE*CONSM solvent as the contaminant is removed, the target values may be attainable. Optimization of the experimental parameters used in the ACT*DE*CONSM process for Mound soil, such as modification of the concentration of chelating and oxidizing agents used, may also prove beneficial. 


\section{Conclusions and Recommendations for Further Work}

The results of the Phase I laboratory study indicate that the ACT*DE*CONSM process could be used to decrease the amounts of contaminants in the Mound soils to acceptisle levels. Additional study is required to determine whether that potential can be realized.

The recommended approach for additional study is to perform a series of investigations designed to resolve issues significant to the deployment of the ACT ${ }^{*} D E^{*} C O N^{S M}$ process at the Mound site. These investigations would begin in the laboratory. On the basis of the advanced lajoratory studies, work would progress to pilot- and full-scale demonstrations. These studies would be Phases II, III, and IV, the tasks and performance goals of which are described in the following sections. (In Phase II, tasks 1 through 8 would be carried out on spiked Mound soil, while tasks 9 and 10 would be carried out on active Mound soil.)

\subsection{Phase II: Laboratory-Scale Optimization}

- Task 1: Test a matrix of three different ethylenediaminetetraacetic acid (EDTA) concentrations and two different $\mathrm{H}_{2} \mathrm{O}_{2}$ concentrations on spiked Mound soil to determine the minimum effective concentrations that provide the maximum or near-maximum decontamination factor.

Performance Goal: The goal of task 1 is to reduce the soil plutonium concentration to less than $0.93 \mathrm{~Bq} / \mathrm{g}$.

- Task 2: Analyze the soil and solution samples from the final test series of task 1 to determine the dissolution of nonhazardous minerals. If appropriate, an additional test series will be run with 8-hydroxyquinoline or other material that may reduce the dissolution of nonhazardous minerals.

Performance Goal: The goal of task 2 is to limit the dissolution of nonhazardous minerals to less than $10 \%$ of the total mineral content present in the pretreated soil.

- Task 3: Evaluate spiked Mound soil to study (1) the residual concentrations of $A C T^{*} D^{*} \mathrm{CON}^{S M}$ chemicals in the treated soil, (2) the mobility in the residual plutonium after treatment, and (3) the ability of the soil to support vegetative growth after decontamination.

Performance Goals: The goals of task 3 are to (1) demonstrate that the residual EDTA concentration in the treated soil is less than $15 \mathrm{ppm}$; (2) demonstrate that 
the mobility of the plutonium in the soil after treatment, as measured by $\mathbf{K}_{\mathbf{d}}$, is not significantly different from the mobility of the plutonium in the soil that has not been treated, and that the mobility after treatment is not in a range that poses a risk that greater levels of plutonium will leach into the aquifer than would be expected for the untreated soil residual; and (3) confirm that three healthy growth cycles can be supported in the sample of treated soil.

- Task 4: Evaluate the ion-exchange effectiveness of several candidate surface adsorbers for the magnetic separation of particles.

Performance Goal: The goal of task 4 is to demonstrate greater than $90 \%$ recovery of plutonium for the selected media in treating the solutions used in the $A C T^{*} D^{*} C^{2} N^{S M}$ process.

- Task 5: Determine the optimal magnetic particle concentration and contact time for the magnetic particles used for recovery of the dissolved plutonium irom the solutions used in the ACT*DE*CONSM process.

Performance Goal: The goal of task 5 is to adsorb $90 \%$ of the dissolved plutonium contained in the $\mathrm{ACT} * \mathrm{DE}^{*} \mathrm{CON}^{\mathrm{SM}}$ /soil slurry by bringing the magnetic separation particles into contact with the solution in a single contact/recovery period.

- Task 6: Evaluate the appropriate regeneration chemistry for recovery and reuse of magnetic particles for plutonium adsorption.

Performance Coals: The goals of task 6 are to (1) regenerate the magnetic particles to $90 \%$ of their initial adsorption capacity and (2) confirm that no adverse effects that are attributable to the natural magnetite content of the soil are encountered in processing.

- Task 7: Evaluate waste-stabilization methods for processing the residues from the treatment process.

Performance Goals: The goals of task 7 are to (1) demonstrate in the lab that the residues can be treated to meet EPA requirements, (2) confirm that the residues can be treated at a cost of less than $\$ 30 / \mathrm{ft}^{3}$ of soil treated, and (3) confirm that the waste product generated by treatment is less than $10 \%$ of the treated soil volume.

- Task 8: Demonstrate in a large-scale laboratory test a combined, integrated treatment process that will dissolve plutonium from soil, recover the dissolved 
plutonium from the soil, regenerate and recover the plutonium from the magnetic separation particles, reuse the magnetic particles for additional plutonium recovery, and stabilize the resulting waste residue (i.e., the combination of tasks 1 through 7).

Performance Goal: The goal of task 8 is to meet each of the individual performance objectives specified during tasks 1 through 7 (not including task 3).

- Task 9: Perform a simple in-beaker dissolution test by using the optimized dissolution chemistry on an active sample from the Mound site.

Performance Goal: The goal of task 9 is to confirm the ability of the process to decontaminate actual Mound soils to less than $0.93 \mathrm{~Bq} / \mathrm{g}$.

- Task 10: After successful demonstration of the ACT*DE*CONSM process in the integrated laboratory-scale tes the test will be rerun with actual contaminated soil from the Mound site.

Performance Goal: The goal of task 10 is to meet each of the individual performance objectives specified during tasks 1 through 7 (not including task 3) with actual soil from a contaminated site.

- Task 11: Perform site hydrogeological studies and testing, if required.

Performance Goal: The goal of task 11 is to obtain sufficient iniformation to model the site hydrogeology at the $85 \%$ confidence level in the Phase III pilotscaie (lysimeter) testing.

- Task 12: Perform magnetic-particle recovery tests by using a small production magnetic filter. Testing will be performed at a variety of unit flow rates $\left(\mathrm{g} / \mathrm{m} \cdot \mathrm{ft}^{2}\right.$ of filter cross-sectional area).

Performance Goal: The goal of task 12 is to demonstrate greater than $99 \%$ particle .ecovery with either one or two magnetic filters in series.

\subsection{Phase III: Pilot-Scale Testing}

- Task 1: Demonstrate that the $A C T * D E * C O N S M$ process can be used in situ to decontaminate plutonium-contaminated soil to less than $0.93 \mathrm{~Bq} / \mathrm{g}$. Active soil 
from the Mound site will be placed in a lysimeter cell to allow a complete mass balance of the test "cell" to assure that no plutonium has been lost from the test system. The pilot-scale demonstration will test all aspects of the integrated treatment system, including the following: solvent distribution and contact with all soil particles, solvent recovery, plutonium dissolution, plutonium recovery by means of the magnetic separation method, magnetic particle recovery and regeneration, recovery of chemicals during cleanup/flushing, and waste processing.

Performance Goal: The goal of task 1 is to demonstrate the ability to meet the performance objectives established for tasks 1 through 7 (not including task 3) of the Phase II study while a pilot-scale in-situ test is performed.

- Task 2: Test the confinement characteristics of the Cryocell ${ }^{\mathrm{TM}}$ cryogenic barrier.

Performance Goal: The goal of task 2 is to demonstrate the ability of the cryogenic barrier to provide zero leakage across the barrier boundary.

\subsection{Phase IV: Full-Scale Demonstration}

- Demonstrate that the ACT*DE*CONSM process can be used to treat plutoniumcontaminated soil in situ. The soil will be contained in a "cell" by means of Cryocell ${ }^{\mathrm{TM}}$ Freeze Barrier technology. The purpose of the cell is to contain the soil and $A C T^{*} D^{*}{ }^{*} \mathrm{CN}^{S M}$ solvents and to prevent the migration of plutonium to uncontaminated areas. The full-scale demonstration will include all aspects of the integrated treatment system, including the following processes: freeze barrier isolation of the treatment area, solvent distribution and contact with all soil particles, solvent recovery, plutonium dissolution, plutonium recovery by means of the magnetic separation method, magnetic particle recovery and regeneration, recovery of chemicals during cleanup/flushing, and waste processing.

Performance Goal: The goal of Phase IV is to decontaminate the soil, in situ, to less than $0.93 \mathrm{~Bq} / \mathrm{g}$ while meeting each of the performance objectives established for Phase II, tasks 1 through 7 (not including task 3), and meeting the performance goal for the cryogenic barrier task of Phase III.

Phases III and IV will need to be integrated with one of the DOE Integrated Demonstration projects so that (1) technologies necessary for this work that have already been demonstrated can be used and (2) technologies that are demonstrated for the first time as part of this project can be made available to other DOE efforts. 
17

Appendix A:

External Analysis Reports 


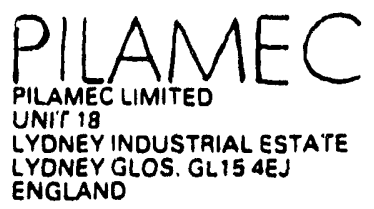

Tel: Dean 10594) 843660 Telegrams: Pilamec

Bradtec Ltd, Bristol Polytechnic, Coldnarbour Lane, BRISTOL, BS16 1QY

For Attention of Mr G Elder

0s116 December 1991 QWP/LVM rour

\section{R.EPORT ON PREPARATION OF SOIL SAMPLE}

Initial visual inspection of the soil showed a very high moisture content. Subsequent sieving of the material would have led to blinding of the mesh.

Therefore, in consultation with customer, it was agreed that we should thoroughly dry material before preparing sample. A laboratory oven, pre-heated to $65^{\circ} \mathrm{C}$, was used to dry the sample.

Large clods of soil were broken down manually and further sizereduction was effected by gently rolling out the coarser material.

Initial sieving through a ómm mesh removed coarse aggregates, whilst the final sample was prepared by sieving through a 400; (38 micron) screen and 'cone and quartering' the fine dust.

END RESULT: $1 \mathrm{~kg}$ representative sample of fine soil particles.

Compiler: E W Pemberton 


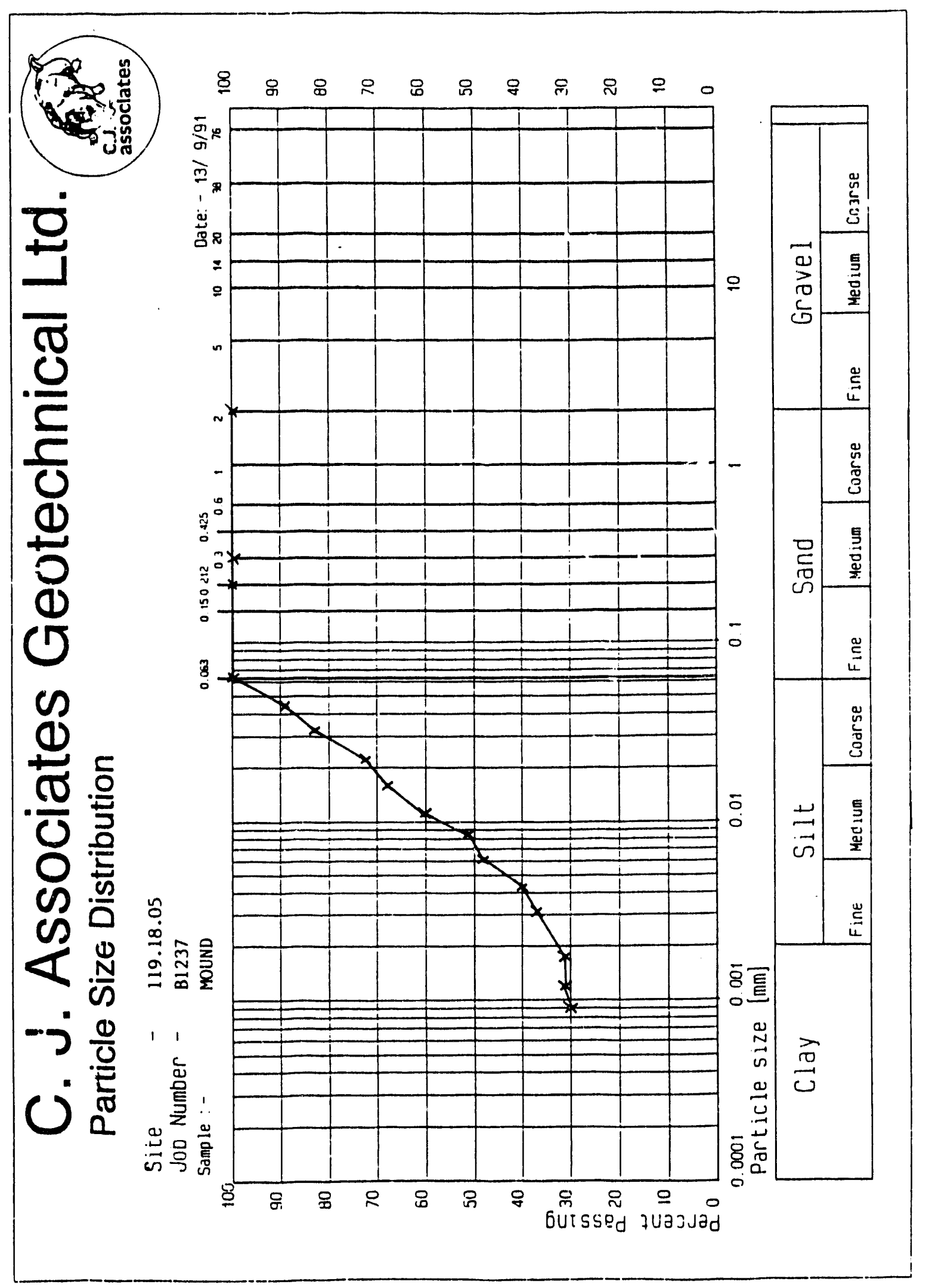


BS1.377 : Part 3 : 1990 . Wethod 3

Dutormination of the organic mattor contont

Sito $\quad 119.19 .05$

Job Number $\quad B 1237$

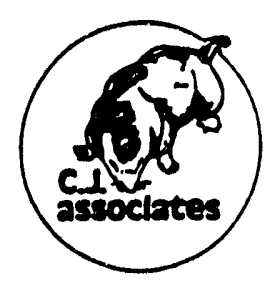

Semplo Reference

Bll Sample Depth [m]

Passine $2 \mathrm{~mm}$ Organic Matter

MOUND 100

TPC

MOUND

$-$

6.4 
Bradtech Ltd.

Science Loading Bay

Bristol Polytechnic

Coldharbour Lane

Bristol

BSI6 1QY

F.A.O. S.M. Scrivens

Ref : Order No $\$ 13$
Analytical Services Unit

Hartley House

London Road

Derby

DE2 8YB

Tel 0332-386624

Ref $241-11-13$

Date $11 / 1 / 92$

\section{ANALYSIS OF SOIL SAMPLES AND SOLL'TIONS}

An analysis has been completed (by Inductively Coupled Plasma) on the three soil samples and four solutions submitted in December. The soil samples were digested as on the previous occasion. All of the result3 are set out below. As before the actual results are quoced for your convenience where a "less than" figure is given but please bear in mind the comments made by my colleague Neil Fearn in his report to you on 22nd November.

1. Soil Samples

\begin{tabular}{|c|c|c|c|c|}
\hline Uranium & $(\mathrm{mg} / \mathrm{Kg})$ & $\begin{array}{l}\text { Sample } 1 \\
50\end{array}$ & $\begin{array}{l}\text { Sample } 2 \\
<50(25)\end{array}$ & $\begin{array}{l}\text { Sample } 3 \\
-50(42)\end{array}$ \\
\hline Thorium & $(\mathrm{mg} / \mathrm{Kg})$ & $.25(\cdot 5)$ & $<25(<5)$ & $<25(<5)$ \\
\hline Iron & $(\mathrm{mg} / \mathrm{Kg})$ & 21400 & 30500 & 13000 \\
\hline Cobalt & $(\mathrm{mg} / \mathrm{Kg})$ & 11 & 16 & 7 \\
\hline Copper & $(\mathrm{mg} / \mathrm{Kg})$ & 9 & 50 & 10 \\
\hline Zinc & $\left(\mathrm{mg} / \mathrm{Kg}_{\mathrm{g}}\right)$ & 33 & 163 & 54 \\
\hline Manganese & (mg/Kg) & 580 & 800 & 330 \\
\hline Sodium & $(\mathrm{mg} / \mathrm{Kg})$ & $<1$ & $<1$ & \\
\hline Calcium & $(\mathrm{mg} / \mathrm{Kg})$ & 20300 & 24600 & 50100 \\
\hline Magnesium & $(\mathrm{mg} / \mathrm{Kg})$ & 6800 & 9100 & 16800 \\
\hline Lead & $(\mathrm{mg} / \mathrm{Kg})$ & 4 & $4 !$ & \\
\hline Cadmium & $(\mathrm{mg} / \mathrm{Kg})$ & 4 & 5 & \\
\hline
\end{tabular}




\title{
NATIONAL PHISICAL LABORATOR Y \\ reddinglu! Middlesix TIVII ULIV lingland
}

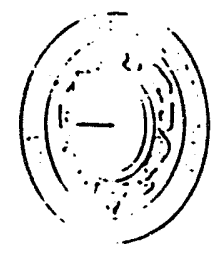

\section{Certilicate of Measurement \\ OF A}

PLUTONIUM-242

LOW-LEVEL STANDARD OF RADIOACTIVITY

\begin{abstract}
DESCRIPTION: $\quad{ }^{242} \mathrm{Pu}$ in the form of a solution in $8 \mathrm{M}$ nitric acid. Supplied as $10 \mathrm{~g}$ nominal of solution in a flamesealed $10 \mathrm{ml}$ British Standard ampoule.
\end{abstract}

IDENTIFICATION: Samples E2061 to E2110

Code R15-00

\section{MEASUREMENTS}

The solution was prepared by gravimetric dilution of a sample which had been assayed by $4 \pi$-alpha liquid scintillation counting. The accuracies of dilution factors were clecked by the use of a liquid scintillation counter.

\section{RESULTS}

${ }^{242} \mathrm{Pu}$ activity concentration $0.999 \mathrm{~Bq} / \mathrm{g}$ at $0000 \mathrm{GMT} 1$ January 19.92.

\section{UNCERTAINTIES}

Overall uncertainty $\pm 4.56 \%$.

Random uncertainty $\pm 0.72 \%$ for 3 degrees of freedom.

Non-random uncertainty $\pm 4.51 \%$ for components added in quadrature.

The uncertainties are at the $95 \%$ confidence level and, except where stated otherwise, the number of degrees of freedom is taken to be infinite. 
Amerahom international ple

Amersnam Laooratories

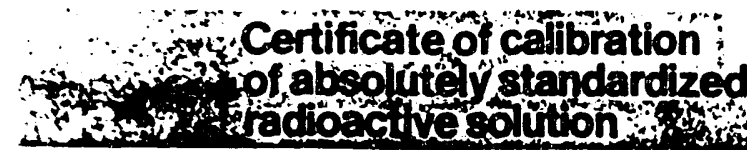

Description

Principal radionuclide: Pluton $m-238$
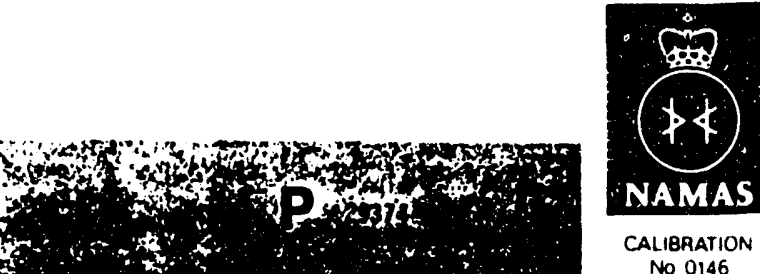

NAMAS

CALIBRATION

Heasurement Reference time:

Radioactive concentration of plutonium-238: which is equivalent to:

Mass of solution:

Total activity of plutontum-238:

wich is equivalent to:
Product code: $\quad$ PPZ.24

Solut ion number: $51 / 25 / 34$
1200 GMT on 1 July 1991

3.974 kilobecquerels per gran of solution

107.4 nanocuries per gram of solution

5.1214 grams

20.35 kilobecquerels

550.0 nanocuries

Method of measurement used (see reverse of the certificate): B

Accuracy

Overall uncertainty in the $r$

$\pm 1.34 x$

Random uncertainty: $\pm 0.71 \times$

Systematic uncertaint $y: \pm 0.63 x$

Overall uncertainty is defined on the reverse of the certificate.

Radionuc lidic

Purity

The estimated activities of any radioactive impurities are listed below expressed as percentages of the activity of the principal radionuclide at the reference $t$ ine.

Other alpha enitters less than $0.004 \%$

Chemical

Carrier free in $0.5 \mathrm{M}$ nitric acid.

Composition

Physical

Data

Recommended half life: $87.7 \pm 0.7$ years

$100 \%$ alpha particle enission.

Remarks

The isotopic purity of the plutonium-238 is greater than 99.97 as determined by mass analysis.

This product meets the quality assurance requirements of NRC Regulatory Guide 4.15 for achieving inplicit NIST traceability as def ined in NCRP 58 (1985).

Approved

Signatory

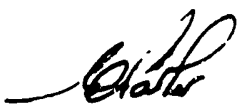

G.D.M.Parker

Page 1 of 1

This centicate is issued in accordance with the congitons of accreditation granteg by the National leasurement Acceditation Service. which

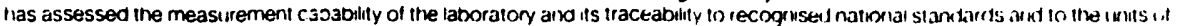


Mothods of messurement

The messurement techniques listed below are currently in use at Amersham International for the absolute standardization of radiosctive solutions. The methods used for this standardization are indicated on the front of the cartificate.

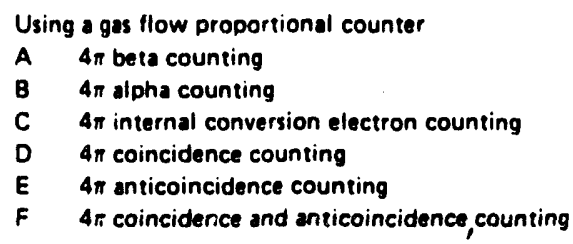

\author{
Using a liquid scintillation counter \\ G $4 \pi$ coincidence counting \\ H $4 \pi$ anticoincidence counting \\ $\mathrm{J} \quad 4 \pi$ coincidence and anticoincidenca counting \\ K $4 \pi$ efficiency tracing
}

S.l. unit of rediosctivity

The S.I. unit of radioactivity is the becquerel

i becquerel $(\mathrm{Bq}) \quad$ - I nuclear transformation per second, therefore

1 curie (Ci) $\quad 3.7 \times 10^{10}$ becquerels excetly.

Usoful conversion factors sre:

1 microcurie $(\mu \mathrm{Ci})=3.7 \times 10^{4} \mathrm{~Bq}=37$ kilobecquerels $(\mathrm{k} \mathrm{Bq})$

1 millicurie $(\mathrm{mCi}) \quad=3.7 \times 10^{7} \mathrm{~Bq} \quad=37$ megabecquerels (MBq)

1 kilobecquerel $(\mathrm{kBa})=27.027$ nanocuries $(\mathrm{nCi})$

1 megabecquerel $(\mathrm{MBQ})=27.027$ microcuries $(\mu \mathrm{Ci})$

Overall Uncertainty

The overall uncertainty was calculated in accordance with the recommendations of the International Commission on Radiation Units and Messurements (ICRU Report 12). The limits of uncertainty were taken as the arithmatic sum of the uncertainty due to random variations, calculated at the $99.7 \%$ confidenca level, and the estimated systematic uncertainties in the measurement. 
AEA ENVIRONMENT

Q ENERGY

AEA TECHNOLOGY

\author{
Building 364 \\ Herwedi \\ Oufordthire OXII ORA \\ Tel: 0235821111 Eat: \\ Direa Dial :434000 \\ Fax 0235432134 \\ Telex: 83135 ATOMHA $G$
}

Dr K J Atkins

Brsdtech Ltd

Bristol Polytechnic

Coldharbour Lane

Bristol

BS16 10Y

21 February 1992

\title{
Dear Karen
}

On 17/2/92 I received from you an intact package containing two plastic vials. The vials were custody sealed on 14/2/92 and their seals were intact. The sampies were logged intu tile sunpie records system and each was given a unique number. The custody seal? were broken to remove sub-samples for analysis.

The results of the $238 \mathrm{Pu}$ determinations are shown on the attached Table.

I hope these results are satisfactory. Please sign and retum the enclosed B/8 form to Joe.

With Best Wishes.

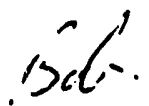

Dr R Carpenter

Enc. 
Pluronium-238 in Soil

\begin{tabular}{llll} 
Our Code & Your Code & Description & ${ }^{238} \mathrm{Pu} \mathrm{Bq} \mathrm{g-1}$ \\
\hline D1272 & Sample A & Mound Soil. 3x treated & $1.88 \pm 0.08$ \\
D1273 & Sample C & Mound Soil. Spiked and blended & $20.3 \pm 0.7$
\end{tabular}

Noles

1. The uncerainties represent 2 counting statistics

$21 / 2 / 92$ 
Page 1 of 2

ANALYTICAL CHEMISTAY LABORATORY

Argonne National Laboratory

Argonne, IL 60439

REPORT OF ANALYTICAL RESULTS

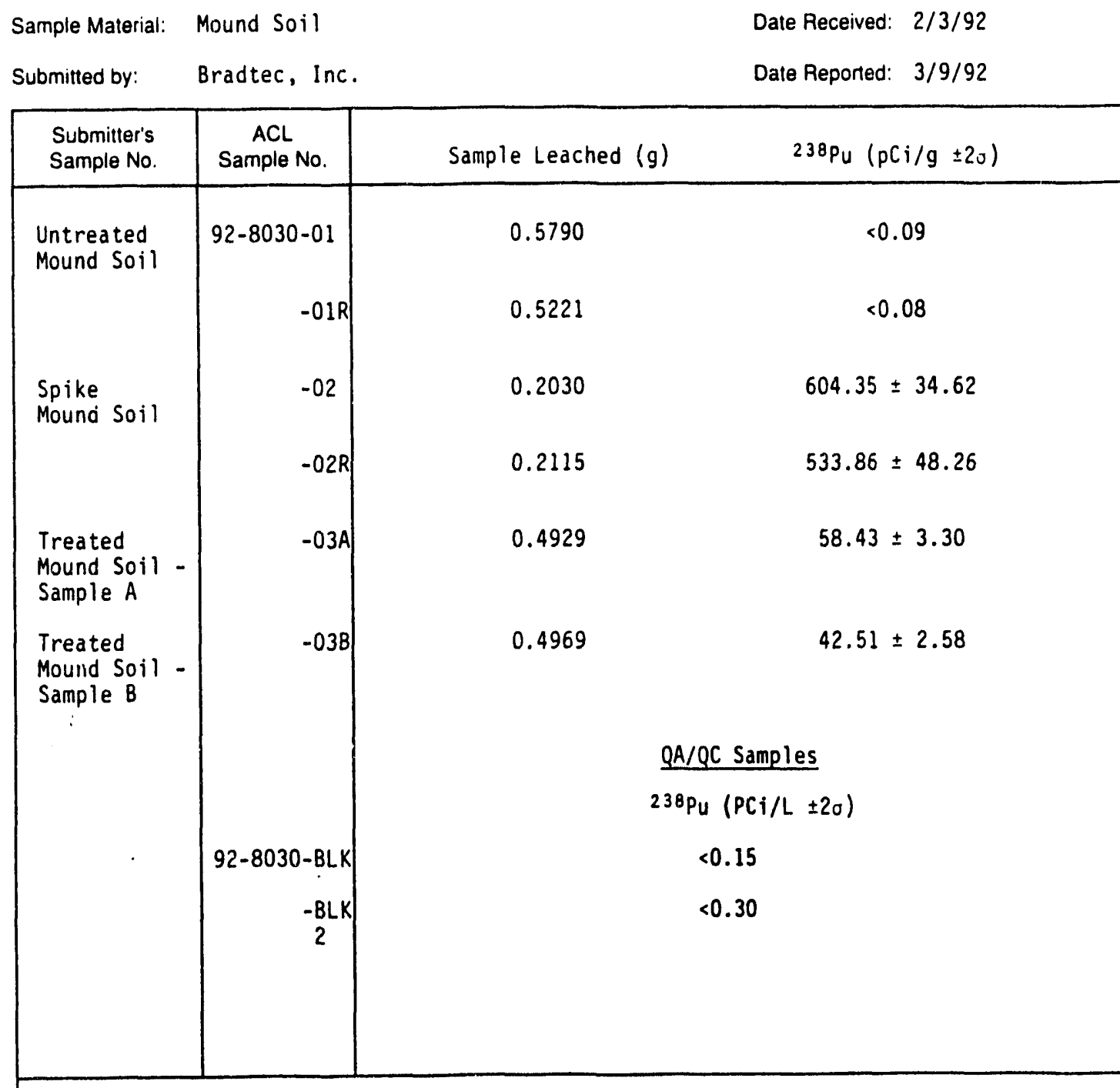

NOTE: Samples will be discarded one (1) month after date of report unless otherwise arranged. When making future inquiries regarding this work, you must reference ACL sample number(s) above. For further information about the results reported here, please call L. Smith, R. Heinrich at $2-7521,4346$

Reference(s): Notebook No. 36863-01, po. 127-130.

$\begin{array}{ll}\text { Copies To: } & \text { Dr. K. Atkins, Bradtec R. Heinrich Analyst(s): L. Smith } \\ & \text { Dr. D. Bradbury, Bradtec L. Smith }\end{array}$

Ivts Dr. G. Elder, Bradtec File

CMT.A. (4.91) D. Green 
Page 2 of 2

ANALYTICAL CHEMISTRY LABORATORY

Argonne National Laboratory

Argonne. IL 60439

\section{REPORT OF ANALYTICAL RESULTS}

$\begin{array}{lll}\text { Sample Material: } & \text { Mound Soil } & \text { Date Received: } 2 / 3 / 92 \\ \text { Submitted by: } & \text { Bradtec, Inc. } & \text { Date Reported: } 3 / 9 / 92\end{array}$

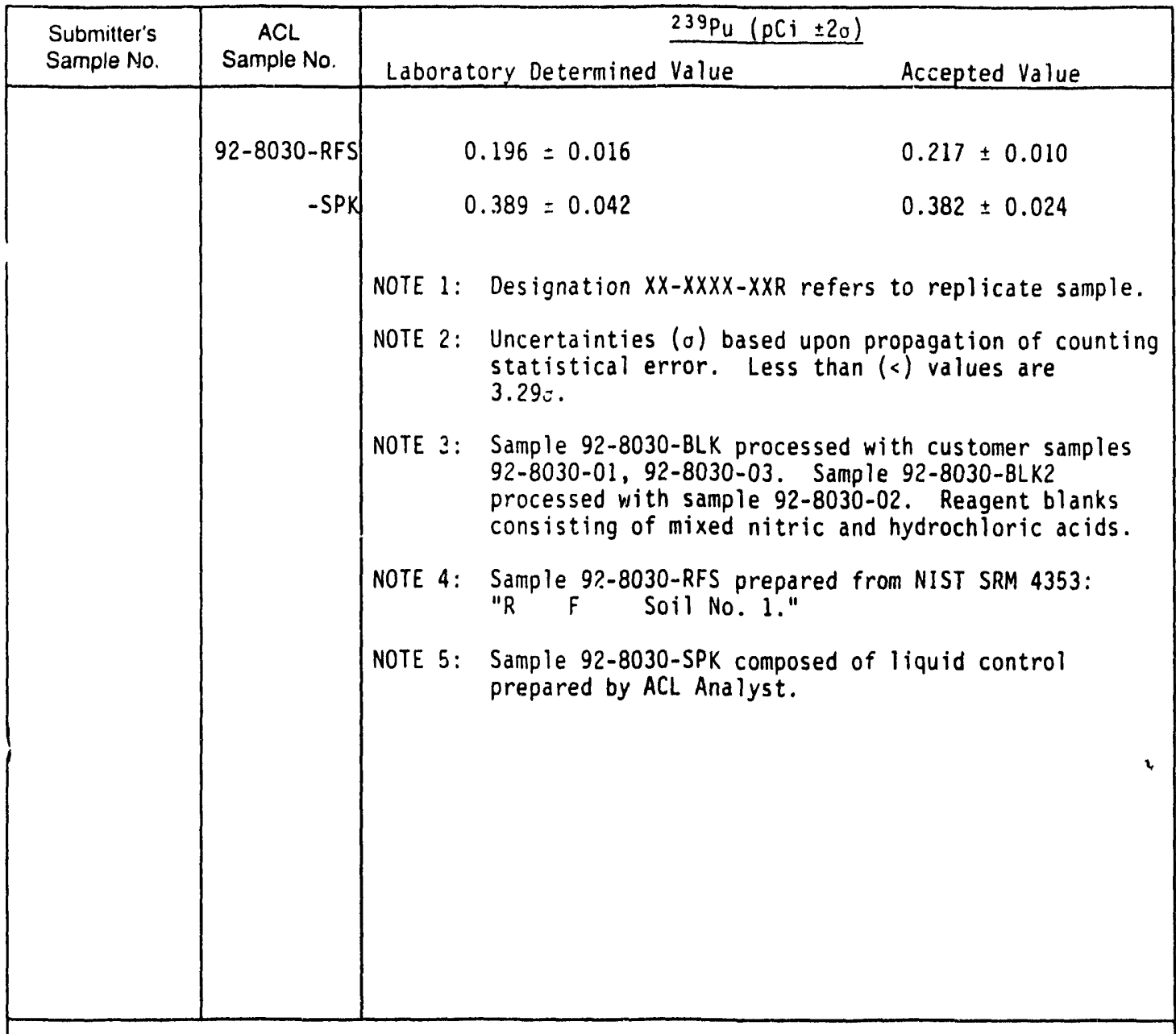

NOTE: Samples will be discarded one (1) month after date of report unless otherwise arranged. When making future inquiries regarding this work, you must reference $A C L$ sample number(s) above. For further intormation about the results reported here, please call L. Smith, R. He inrich at 2 - 7521,4346

Relerence(s): Notebook No. 36963-01, pp. 127-130. 


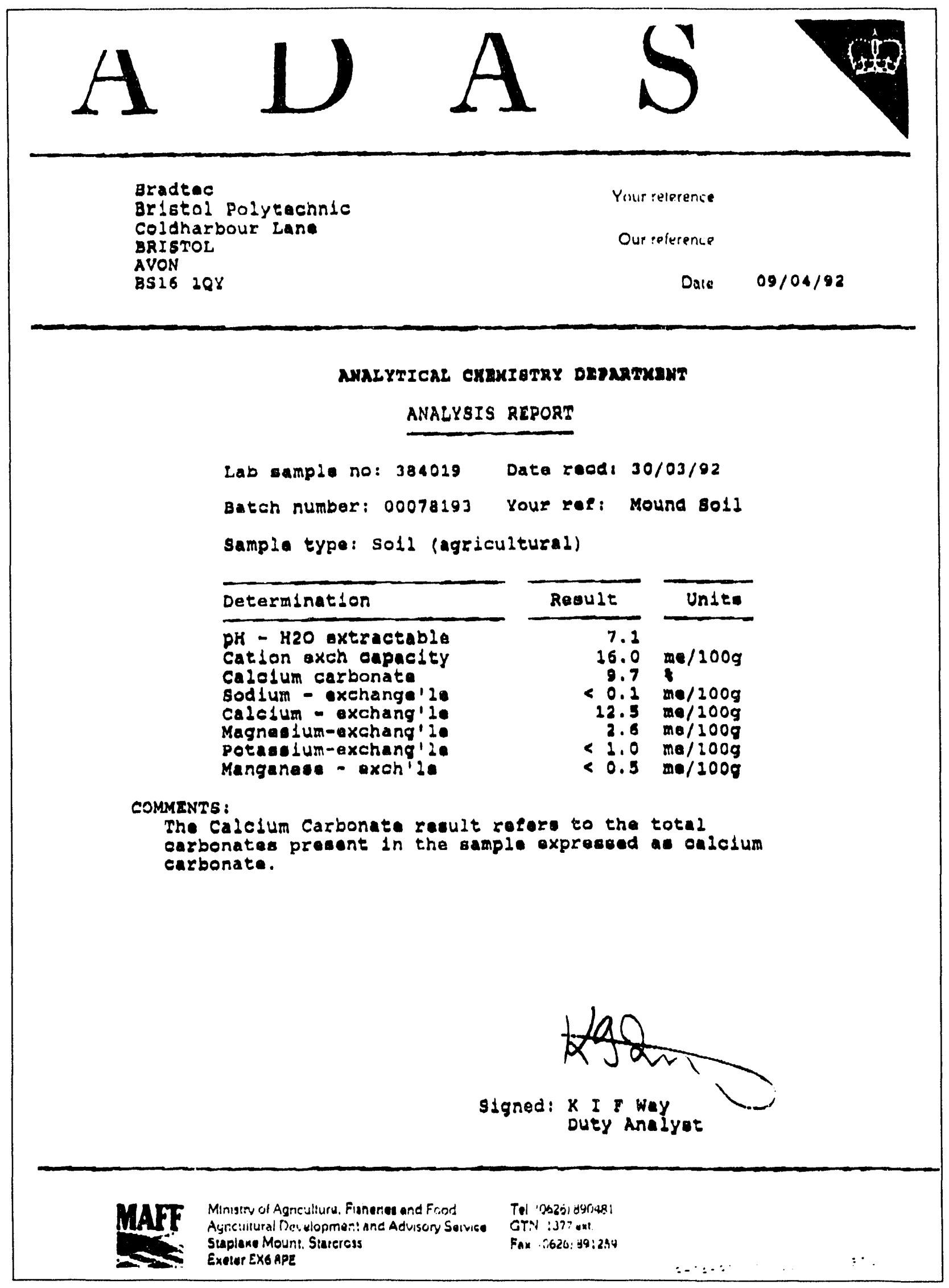


Addendum to report 04/92 - Plutonlum-238 recovery from Mound soil using ACT"DE"CON

In accordance with Argonne National Laboratories - work order number 1, data for pH. Eh. carbonate content and cation exchange capacity is as follows:

1. $\mathrm{pH}=7.1$

2. $E h=265 \pm 2 \mathrm{mV}$

3. Calcium carbonate content $=9.7 \%$

4. Cation Exchange Capacity $=16.0 \mathrm{meg} / 100 \mathrm{~g}$

Note: Analyses 1,3 and 4 were performed by the Ministry of Agriculture, Fisheries and Food (MAFF), Agricuiture Development and Adrisory Service, Staplake Mount, Starcross, Exeter. EX6 8PE. UK. Eh analysis

of the Mound soil was performed by Bradtec Ltd in accordance with standard analytical methods. A $1: 1$ weight ratio of soil in water was analysed using a combination platinum electrode referenced with a silverisilver chloride electrode. 
Appendix B:

Recovery of Pu-238 from Mound Soll by Means of the ACT*DE*CONSM Process: Soll Splking and Pu-238 Dissolution 


\section{Appendix B: \\ Recovery of Pu-238 from Mound Soll by Means of \\ the ACT"DE"CONSM Process: Soll Spiking and Pu-238 Dissolution}

\section{B.1 Soll Preparation ${ }^{\dagger}$}

1. Take $3 \mathrm{~g}$ of the Mound soil that has been dried at $<70^{\circ} \mathrm{C}$ and sieved. The soil fraction that was less than $38 \mu \mathrm{m}$ should be used.

Weight of soil and beaker: $68.51742 \mathrm{~g}$

Weight of beaker: $65.50832 \mathrm{~g}$

Weight of soil: $3.0091 \mathrm{~g}$

2. Suspend the soil in $2.5 \mathrm{~mL}$ of $0.1 \mathrm{~N} \mathrm{HNO}_{3}$ and $6 \mathrm{~mL}$ of water. Stir the solution.

3. Add $1500 \mu \mathrm{L}$ of $\mathrm{Pu}-238$ standard (corresponding to $300 \mathrm{~Bq}$ ) one drop at a time to a $0.5 \mathrm{~N}$ solution of $\mathrm{HNO}_{3}$ while the solution is constantly stirred. The molarity of the final $\mathrm{HNO}_{3}$ solution will be 0.1 .

4. Leave the solution stirring and in contact with the Pu-238 until the solution is required.

Start: $1045 \mathrm{~h}$

Finish: $1415 \mathrm{~h}$

Contact time: $3.5 \mathrm{~h}$

5. Filter the solution through a $2-\mu \mathrm{m}$ glass-fiber filter paper.

6. Retain the original soak liquor.

Volume of liquor: $16.7 \mathrm{~mL}$

† Completion of soil preparation witnessed by Robert Heinrich, Argonne National Laboratory. 
7. Add $25.3 \mathrm{~mL}$ of concentrated $\mathrm{HNO}_{3}$ to the original soil soak liquor plus $1 \mathrm{~mL}$ of $\mathrm{Pu}-242$ tracer in $8 \mathrm{M} \mathrm{HNO}_{3}$. Place the sample to one side for analysis. Make up to $50 \mathrm{~mL}$ of solution with water prior to analysis to yield a final acid concentration of $8 \mathrm{M} \mathrm{HNO}_{3}$.

8. Wash the soil three times with $10 \mathrm{~mL}$ of $18 \mathrm{M} \Omega$ water.

9. Filter the suspension and retain each wash solution. Record the volume of each.

Volume of first wash: $15.0 \mathrm{~mL}$

Volume of second wash: $9.8 \mathrm{~mL}$

Volume of third wash: $10.3 \mathrm{~mL}$

10. Add $12.7 \mathrm{~mL}$ of concentrated $\mathrm{HNO}_{3}$ to each of the samples. Add $1 \mathrm{~mL}$ of $\mathrm{Pu}-242$ tracer in $8 \mathrm{M} \mathrm{HNO}_{3}$ to the third wash solution. The samples should then be made up to $25 \mathrm{~mL}$ with water prior to analysis. Samples over $12 \mathrm{~mL}$ in volume should have $25.3 \mathrm{~mL}$ of concentrated $\mathrm{HNO}_{3}$ added and should be made up to $50 \mathrm{~mL}$ of solution with water prior to analysis. The final acidity of these samples will then be $8 \mathrm{M} \mathrm{HNO}_{3}$.

11. Transfer the spiked soil to a $200-\mathrm{mL}$ beaker with $50 \mathrm{~mL}$ of water.

12. Add $12 \mathrm{~g}$ of unspiked Mound soil to the beaker.

Weight of soil and beaker: $15.59429 \mathrm{~g}$

Weight of beaker: $3.59888 \mathrm{~g}$

Weight of soil: $11.99541 \mathrm{~g}$

13. Thoroughly mix and stir the soils together.

14. Divide the solution and place it into $50-\mathrm{mL}$ centrifuge tubes and spin the tubes at 3000 revolutions per minute (rpm) for $10 \mathrm{~min}$.

15. Filter the supernatant. Retain this first wash solution.

Volume of wash: $66 \mathrm{~mL}$ 
16. Add $50 \mathrm{~mL}$ concentrated $\mathrm{HNO}_{3}$ to this wash solution in a plastic bottle. Add $1 \mathrm{~mL} \mathrm{Pu}-242$ tracer and make up to $100 \mathrm{~mL}$ of sclution with water prior to analysis.

17. Dry the soil at $<70^{\circ} \mathrm{C}$ and weigh separately three lots of soil.

18. Place one aliquot of soil in a reaction flask: sample $\mathbf{A}$

Weight of flask and soil: $6.76059 \mathrm{~g}$

Weight of flask: $1.74290 \mathrm{~g}$

Weight of soil: $5.01769 \mathrm{~g}$

19. Place a second aliquot of soil in another reaction flask: sample B

Weight of flask and soil: $7.43674 \mathrm{~g}$

Weight of flask: $2.43277 \mathrm{~g}$

Weight of soil: $5.00397 \mathrm{~g}$

20. Place the third aliquot of soil in a sample vial: sample $\mathbf{C}$

Weight of flask and soil: $9.35878 \mathrm{~g}$

Weight of flask: $4.97619 \mathrm{~g}$

Weight of soil: $4.38259 \mathrm{~g}$

21. Remove a 1-g aliquot of soil from the third aliquot for the Argonne Analytical Chemistry Laboratory.

Weight of bottle and soil: $6.11462 \mathrm{~g}$

Weight of bottle: $5.10785 \mathrm{~g}$

Weight of soil: $1.00677 \mathrm{~g}$ 
22. Weigh a second $1-\mathrm{g}$ aliquot of the soil sample $\mathbf{C}$ for an acid digest.

Weight of bottle and soil: $3.35396 \mathrm{~g}$

Weight of bottle: $2.35452 \mathrm{~g}$

Weight of soil: $0.99944 \mathrm{~g}$

23. Add $1 \mathrm{~mL}$ of $\mathrm{Pu}-242$ tracer to the second $1-\mathrm{g}$ soil aliquot and leach the soil by using $20 \mathrm{~mL}$ of ANALAR-grade nitric acid and $5 \mathrm{~mL}$ of ANALAR-grade hydrochloric acid. After a 1-h digest period, add $5 \mathrm{~mL}$ of nitric acid and $2 \mathrm{~mL}$ of hydrochloric acid.

24. Digest the soil for several hours.

Date: December 18, 1991

Start Tima: $1730 \mathrm{~h}$

Finish: $2000 \mathrm{~h}$

Digest Time: $2.5 \mathrm{~h}$

25. Filter the soil sample through a $2-\mu \mathrm{m}$ filter.

26. Wash the soil three times with $8 \mathrm{M} \mathrm{HNO}_{3}$.

27. Transfer the leachate plus washings to an evaporating dish and evaporate the material to dryness.

28. Resuspend the solid in $8 \mathrm{M} \mathrm{HNO}_{3}$. Retain the solution for analysis.

29. Retain the soil and dry it at $<70^{\circ} \mathrm{C}$. 


\section{B.2 Dissolution Procedure - Outline Form ${ }^{\dagger}$}

1. Suspend samples $A$ and $B$ separately in the chemicals used for the ACT ${ }^{*} D E^{*} C O N^{S M}$ process. Stir the solutions thoroughly.

2. Record the time of the first dissolution reaction as time zero.

3. Allow the soil suspensions to stir for $1 \mathrm{~h}$.

4. At $1 \mathrm{~h}$, remove a $10-\mathrm{mL}$ sample from each soil sample.

5. Immediately filter both solutions. Record the volume of each sample.

6. Transfer each sample to a scintillation vial. Add $12.7 \mathrm{~mL}$ of concentrated $\mathrm{HNO}_{3}$ and $1 \mathrm{~mL}$ of $\mathrm{Pu}-242$ tracer in $8 \mathrm{M} \mathrm{HNO}_{3}$ to each solution and keep the solutions for analysis.

7. Divide the remainder of the soil solutions from samples $\mathbf{A}$ and $\mathbf{B}$ into centrifuge tubes and spin the tubes at $3000 \mathrm{rpm}$ for $10 \mathrm{~min}$. Filter the supernatant from the first dissolution liquor for each sample.

8. Record the volume of each solution.

9. Add $127 \mathrm{~mL}$ of concentrated $\mathrm{HNO}_{3}$ to each solution. Add $1 \mathrm{~mL}$ of $\mathrm{Pu}-242$ tracer and make up to $250 \mathrm{~mL}$ of solution prior to analysis.

10. Resuspend the soil samples in $100 \mathrm{~mL}$ of $A C T * D E * C O N S M$ solution. Stir the suspension thoroughly.

11. Record the time of the second dissolution reaction as time zero.

12. Allow the soil suspension to stir for $1 \mathrm{~h}$.

13. At $1 \mathrm{~h}$, remove a $10-\mathrm{mL}$ sample from each soil sample.

14. Immediately filter both solutions. Record the volume of each sample.

\footnotetext{
${ }^{\dagger} \mathrm{ACT} * \mathrm{DE}^{*} \mathrm{CON}^{\mathrm{SM}}$ dissolution witnessed by Robert Heinrich, Argonne National Laboratory.
} 
15. Transfer each sample to a scintillation vial. Add $12.7 \mathrm{~mL}$ of concentrated $\mathrm{HNO}_{3}$ and $1 \mathrm{~mL}$ of Pu-242 tracer in $8 \mathrm{M} \mathrm{HNO}_{3}$ to each sample and keep the solutions for analysis.

16. Divide the remainder of the soil solutions from samples $A$ and $B$ into centrifuge tubes and spin the tubes at $3000 \mathrm{rpm}$ for $10 \mathrm{~min}$. Filter the supernatant from the second dissolution liquor for each sample.

17. Record the volume of each solution.

18. Add $127 \mathrm{~mL}$ of concentrated $\mathrm{HNO}_{3}$ to each solution. Add $1 \mathrm{~mL}$ of $\mathrm{Pu}-242$ tracer and make up to $250 \mathrm{~mL}$ of solution with water prior to analysis.

19. Resuspend the soil samples in $100 \mathrm{~mL}$ of $A C T * D E * C O N^{S M}$ solution. Stir the suspension thoroughly.

20. Record the time of the third dissolution reaction as time zero.

21. Allow the soil suspension to stir for $1 \mathrm{~h}$.

22. At $1 \mathrm{~h}$, remove a $10-\mathrm{mL}$ sample from each soil sample.

23. Immediately filter both solutions. Record the volume of each sample.

24. Transfer each sample to a scintillation vial. Add $12.7 \mathrm{~mL}$ of concentrated $\mathrm{HNO}_{3}$ and $1 \mathrm{~mL}$ of $\mathrm{Pu}-242$ tracer in $8 \mathrm{M} \mathrm{HNO}_{3}$ to each sample and keep the solutions for analysis.

25. Divide the remainder of the soil solutions from samples A and B into centrifuge tubes and spin at $3000 \mathrm{rpm}$ for $10 \mathrm{~min}$. Filter the supernatant from the third dissolution liquor for each sample.

26. Record the volume of each solution.

27. Add $127 \mathrm{~mL}$ of concentrated $\mathrm{HNO}_{3}$ to each solution. Add $1 \mathrm{~mL}$ of $\mathrm{Pu}-242$ tracer prior to analysis and make up to $250 \mathrm{~mL}$ of solution with water prior to analysis.

28. Dry each of the soil samples at $<70^{\circ} \mathrm{C}$.

29. Record the weight of each leached soil sample. 
30. Remove a 1-g aliquot of soil from each sample for Argonne National Laboratory.

31. Transfer the remainder of each soil sample to a $250-\mathrm{mL}$ beaker.

32. Leach $1 \mathrm{~g}$ of each of the soil samples by using $20 \mathrm{~mL}$ of ANALAR-grade concentrated $\mathrm{HCl}$. Spike each of the soils with $1 \mathrm{~mL}$ of $\mathrm{Pu}-242$ in $8 \mathrm{M} \mathrm{HNO}_{3}$.

33. After $1 \mathrm{~h}$, add $5 \mathrm{~mL}$ of concentrated $\mathrm{HNO}_{3}$ and $2 \mathrm{~mL}$ of concentrated $\mathrm{HCl}$.

34. Digest the soils for several hours.

35. Filter the soil samples through a $2-\mu \mathrm{m}$ filter.

36. Wash the soil three times with $8 \mathrm{MHNO}_{3}$.

37. Transfer the leachate plus washings to an evaporating dish and evaporate the material to dryness.

38. Resuspend each solid in $8 \mathrm{M} \mathrm{HNO}_{3}$ and add $1 \mathrm{~mL}$ of $\mathrm{Pu}-242$ tracer. Retain each solution for analysis.

39. Retain the soil and dry it at $<70^{\circ} \mathrm{C}$.

40. Archive the remainder of the soil. 


\section{Distribution for ANL/ESD-15}

Internal

ANL Contract Copy

K.S. Macal (8)

ANL Patent Department

D.O. Johnson (200)

ANL Technical Publications Services (3)

\section{External}

U.S. Department of Energy Office of Scientific and Technical Information (12) Manager, U.S. Department of Energy Chicago Operations Office

ANL Libraries (2) 
$\nabla$
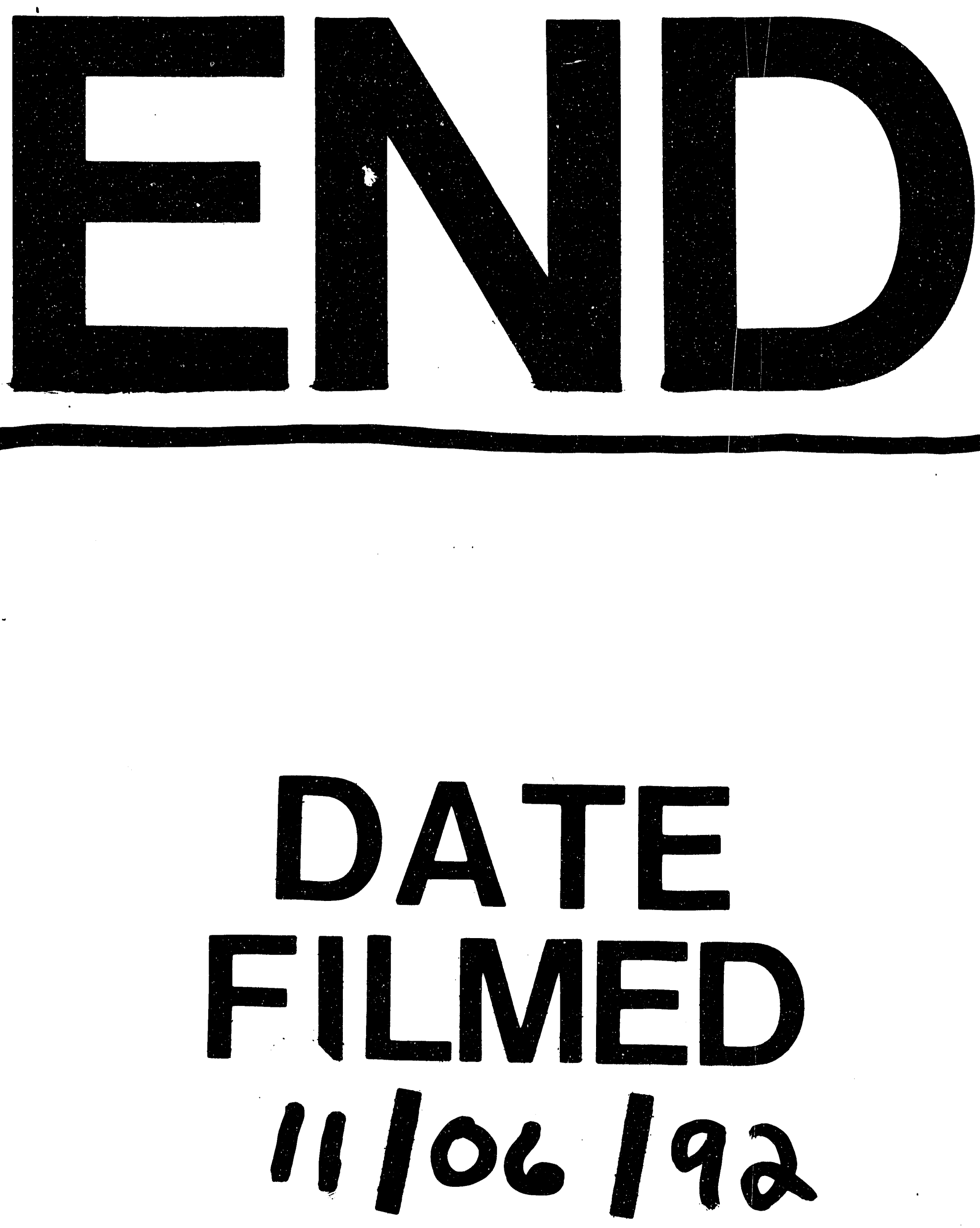
